\title{
Penicillin-G and oxytetracycline residues in beef sold for human consumption in Maroua, Cameroon
}

\author{
Ronald Romuald B. Vougat Ngom ${ }^{1 *}$, Rebecca B. Garabed ${ }^{2}$, Wilson K. Rumbeiha ${ }^{3}$, Harquin Simplice Foyet ${ }^{1}$, \\ Dwayne E. Schrunk ${ }^{3}$, Dahai Shao ${ }^{3}$ and André Zoli Pagnah ${ }^{4}$
}

\begin{abstract}
Background: The contamination of food by chemical hazards is a worldwide public health concern and is a leading cause of trade problems internationally. Based on former work describing the prevalent use and misuse of antibiotics in cattle in the Far North Region of Cameroon, we designed a study to detect antibiotic (penicillin $\mathrm{G}$ and oxytetracycline) in beef sold for human consumption in Maroua (Cameroon). To determine the mean concentration of antibiotic residues in beef, sample of liver and muscle were collected from 202 cattle selected randomly in all the slaughterhouses of Maroua and Godola and analyzed using Liquid Chromatographic tandem Mass Spectrometry (LC-MS/MS). Characteristics of the cattle selected (age, sex, breed, body condition score, weight, production system, and pathology, etc.) were also collected before and/or after slaughter - by physical examination and survey, and post mortem examination.
\end{abstract}

Results: Results revealed that out of 202 cattle 41 (20.30\%) tested positive for antibiotics in one or more of their organs. The meat of cattle from transhumance system, sick animals and older cattle was more likely to be contained with penicillin $\mathrm{G}$ and oxytetracycline residues. The average residues concentration in beef was $17.58 \mu \mathrm{g} /$ $\mathrm{kg}$ for penicillin $\mathrm{G}$ and $240 \mathrm{\mu g} / \mathrm{kg}$ for oxytetracycline.

Conclusions: The findings of the present study should be alarming for the legislative authorities in food security and safety. This highlights a very serious problem, both for the consumers of Maroua city and the herders of the region as well as for the whole economy of Cameroon. It is therefore be important that measures be taken at several levels by the actors of the sector (public authorities, veterinary auxiliaries, etc.) to guarantee the safety of the food of animal origin.

Keywords: Oxytetracycline, Penicillin-G, Beef, Residues

\section{Background}

In several countries around the world, there are specialized organizations to monitor veterinary drugs in foods of animal origin (Kang et al. 2015). For example in United Kingdom, the statutory surveillance programme is operated by the Veterinary Medicines Directorate (VMD 2011) and in US we have the National Residue Program (FSIS 2011). In Cameroon as in many african countries, Few controls are made on the quality and

\footnotetext{
* Correspondence: romsonbey@yahoo.fr

'Department of Biological Sciences, Faculty of Sciences, University of Maroua, P.O Box: 814, Maroua, Cameroon

Full list of author information is available at the end of the article
}

safety of these products. Certain safety standards do exist but are still yet to be enforced. Inspections done so far by regulatory authorities are partial and do not cover important hazards that require laboratory analysis (Pouokam et al. 2017). Food containing drug residues are considered to be a public health hazard (Chicoine 2007). When animal products with high levels of veterinary drug residues are ingested by humans, there is occurrence numerous adverse health effects like permanent gene mutation, liver poisoning (Nisha 2008), development of allergic reactions in some hypersensitive individuals, increased risk of carcinogenicity (Petrović et al. 2008; Hou et al. 2014), growth of resistant bacterial 
strains, and imbalances in intestinal microflora (Wang et al. 2006; Borràs et al. 2011).

Hazards in foods of animal origin are gratually considered as public health threats in africa. In Cameroon, consumption of animal products covered up to $8.1 \%$ of the total diet (Pouokam et al. 2017). In this country where cattle breeding is a lever for the economic development of the country (Messomo 2006), very few studies have been carried out by researchers in this domain. Only the work carried out by Edima et al. (2012) on cow's milk and Guetiya et al. (2016) on eggs have been done. No study has been carried out on meat, which is a very important foodstuffs for Cameroonians (Vougat et al. 2016). For example, cooked beef represent $9.86 \mathrm{~g} /$ day/ Adult Equivalent (AE) and poultry meat consumption accounted for 9.81g/day/AE (Pouokam et al. 2017). The bovine sector is the main channel chosen in the livestock sector under the Three-Year Emergency Plan for Growth and Employment put in place by the President of the $\mathrm{Re}$ public of Cameroon to speed up the economy growth and improve living conditions for population.

As the country plans to export beef, is it therefore essential to assess the extent of this problem in Cameroon. The presence of veterinary drug residues in foodstuffs of animal origin may jeopardize international trade following the World Trade Organization's agreements on the application of sanitary and phytosanitary measures establishing the globalization of markets (Chillaud 1996). This was all the most necessary in the case of Cameroon where the previous studies highlighted the extensive misuse of veterinary medicines in beef production areas (Vougat et al. 2017). The main causes of antibiotics residues in animal products have been attribute to the misuse of drugs (Donkor et al. 2011; Bousova et al. 2013).

The Far North Region of Cameroon has the second cattle population (24.7\%) of the country (MINEPIA 2015). In this region, pastoralists generally treat their animal's using drug without following the recommended dosage, frequency, duration, and withdrawal period. The most commonly used medications by these herders are procaine penicillin G and oxytetracycline (Vougat et al. 2017).

The dual purpose of this study is to determine, on one hand the proportion of animals whose carcasses are contaminated with penicillin $\mathrm{G}$ and oxytetracycline residues in Maroua (Far North of Cameroon); and in the other hand to estimate the concentration of residues of these antibiotics in the beef consumed in Maroua town. According to the Codex Alimentarius Commission

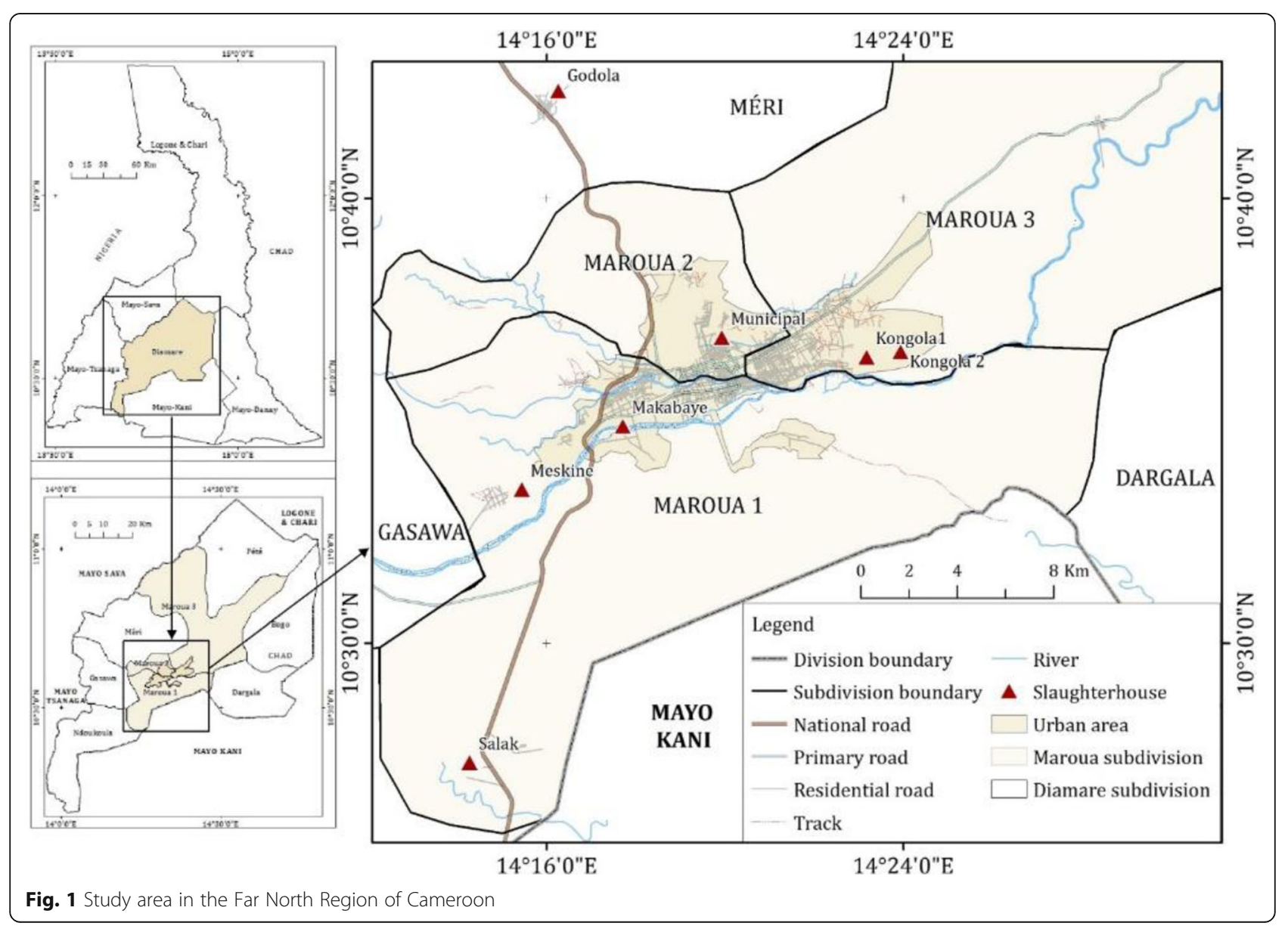


regulation the maximum residual limits of oxytetracycline in muscle and liver are 200 and $600 \mu \mathrm{g} / \mathrm{kg}$ respectively while penicillin G should not exceed $50 \mu \mathrm{g} / \mathrm{kg}$ in both tissues (CAC/MRL 2015).

\section{Methods}

\section{Study area}

This study was carried out in the Far North region of Cameroon and especially in Maroua and Godola towns. It covered all of Maroua town slaughterhouses (Makabaye, Municipal, Kongola [1 and 2], Meskine and Salak) and the Godola slaughterhouse located $10 \mathrm{~km}$ from Maroua (Fig. 1). Godola slaughterhouse was also chose because most of the beef from this slaughterhouse is sold in Maroua (Report of Far North Regional delegation of MINEPIA 2014-unpublished).

\section{Samples collection}

Due to the lack of data related to this subject in our study area in particular and in Cameroon in general, and due to the difficulty of doing preliminary test (due to lack of technology) in order to estimate the probability of having beef contaminated with residues of veterinary medicines, we proceeded with the assumption that the positive sample rate is $20 \%$. This assumption is based on the results of our previous research (Vougat et al. 2017). The choice of a $95 \%$ confidence interval and a $10 \%$ accuracy enabled us to have a minimum sample size of 61 cattle using the formula below (Thrusfield 2007):

$$
\mathrm{N}=\frac{p(1-p) Z^{2}}{i^{2}}
$$

For a $95 \%$ confidence interval, $\mathrm{Z}=1.96$, $\mathrm{i}$ is the accuracy, $\mathrm{p}$ the percentage of contaminated cattle or prevalence, and $\mathrm{N}$ is the sample size.

To increase the reliability of our data, we planned to sample 200 cattle instead of 61. Thus, taking into account the number of cattle slaughtered in each slaughterhouse in our sample, 115, 45, and 26 cattle were respectively sampled in the Municipal, Makabaye and Kongola slaughterhouses. In the Meskine and Salak slaughterhouses, 8 and 5 cattle were sampled respectively. At Godola slaughterhouse data was collected on 3 cattle instead of 2 to have a reliable statistics. Indeed, according to the regional report of MINEPIA in April 2014, 58\% of cattle slaughtered in Maroua per week came from Municipal slaughterhouse while 22, 13, 4, 2 and $1 \%$ are respectively from the slaughterhouses of Makabaye, Kongola, Meskine, Salak, and Godola.

The collection of samples from these slaughterhouses was done between mid-May and June because it was during this period that the majority of herders in the Far North region treat their animals (Moritz et al. 2016).
Finally, to quantify antibiotic residues in beef, approximately $200 \mathrm{~g}$ of liver (Keegan et al. 2011) and $200 \mathrm{~g}$ of muscle were post-mortem collected from each of 202 randomly selected cattle in the Maroua and Godola slaughterhouse. The butcher's authorization was obtained prior to collection. The demographics of the cattle like age (FAO 1995), sex, body condition score (Nicholson and Butterworth 1989), weight (Crévat 1980; Pater 2007), breed, production system, type of production, town of origin, and health status (Dongmo et al. 2007; Djamen 2008) were also collected before and/or after slaughter by physical examination and survey, and post mortem examination, respectively. All those parameters were collected because they can influence the prevalence of drug residues in the animal body (Kaneene and Miller 1997; Beyene 2016).

Collected samples were sealed in a polystyrene plastic bag (Ziploc bag), labeled on a card (OIE, 2008) designed for this purpose and the securely transported under refrigeration to the laboratory for storing at freezer temperature $\left(-20^{\circ} \mathrm{C}\right)$ till analysis.

Determination of penicillin $\mathrm{G}$ and oxytetracycline residues Liquid chromatography (LC) tandem mass spectrometry (LC-MS/MS) was used for the determination of residues according to the revised method of the United States Department of Agriculture (USDA 2014a) followed by some modifications. The McIlvaine buffer was used to satisfy USA protocols APHIS (animal and plant health inspection service) for foot and mouth virus inactivation prior to entry in US (USDA 2014b). Details of the chemical analysis methods used can be found in Additional file 1.

\section{Data analysis}

Data collected in the slaughterhouses were entered directly into the Statistical Package for Social Sciences (SPSS) software version $20.0\left(\mathrm{IBM}^{\bullet}\right.$ SPSS $^{\circ}$ Statistics version 20.0, http://www-01.ibm.com/support/docview.wss?uid=swg24029274). This enabled us to calculate the descriptive statistics for all the characteristics evaluated and the chi-squared test was applied to compare the percentage.

However, Statgraphics version 5.0 (Windows, www.Statgraphics.com) via the Duncan Multiple Comparison Test enabled the comparison of body weight of cattle. The same analysis was used for comparison of the concentration of residues according to animal demographics.

The mass spectra from the LC-MS/MS antibiotic residue assay were acquired and processed using MassLynxTM 4.1 SNC 714 (Water Corporation 2009). The processed data was then transported to GraphPad 
Prism version 5.00 for Windows (GraphPad Software, San Diego California USA, www.graphpad.com), for analysis. For each variable (age, sex, breed, production system, type of production, etc.), the Chi square test was performed to compare the percentage of contaminated cattle carcass.

\section{Results}

\section{Demographics of sampled cattle}

The majority of the cattle sampled (23.35\%) were 10 years old. However, $21.67 \%$ of the females were under 8 years old and $23.08 \%$ of males were $<4$ years old. All castrated cattle were at least 4 years old.

The majority (91.58\%) of slaughtered animals were female. This percentage is significantly higher $(p<0.001)$ than that of the entire male (6.44\%) and castrated cattle (1.98\%). $47.52 \%$ of the animals in the sample belong to the Red Fulani breed. The other most represented breeds were White Fulani (32.18\%) and Goudali (6.44\%).

$86.93 \%$ of cattle subjected to an ante-mortem examination were found to be free of all diseases or abnormalities and $7.54 \%$ had dermatophilosis.

The results of the post-mortem examination shows that $84.58 \%$ of the animal were not sick and the remaining were diagnosed positive for at least one of the following diseases: liver abscesses, tuberculosis, Echinochocose and distomatosis. However, results of the ante and post mortem examinations revealed that all the cattle from the slaughterhouse of Godola were sick.

About $62.19 \%$ of the animals sampled in our study area come from extensive system for meat and milk production. This proportion is significantly higher $(p<0.05)$ compared to the number of cattle which come from semi-intensive breeding (22.89\%). Data on production system showed that $79.49 \%$ of the cattle identified came from sedentary farming, while the other $(20.51 \%)$ came from transhumant production system.

The majority of cattle sampled $(65.17 \%)$ were thin, only one animal was fat (score 8). There was no statistical difference $(p<0.05)$ between the number of animals in the different classes (score 1, 2 and 3) of thin cattle. In contrast, among animals which have a normal BCS (34.33\% of the herd), those with a score of 4 were significantly more numerous $(22.89 \%)$ than those in the other subclasses of this category (5 and 6).

Similarly, the average body weight of the sampled cattle was $170.50 \pm 18.98 \mathrm{~kg}$. However, the Duncan test preceded by ANOVA shows a significant difference $(\mathrm{p}<0.05)$ between the weight of animals slaughtered in Kodola $(171.51 \pm 28.41 \mathrm{~kg})$ and Makabaye $(157.24 \pm 30.19 \mathrm{~kg})$ and those of Makabaye and Municipal $(175.66 \pm 23.31 \mathrm{~kg})$. The average weight of animals slaughtered in Meskine, Godola and Salak were $176.24 \pm 13.34 \mathrm{~kg} ; 179.21 \pm$ $27.52 \mathrm{~kg}$ and $160.75 \pm 27.92 \mathrm{~kg}$ respectively.

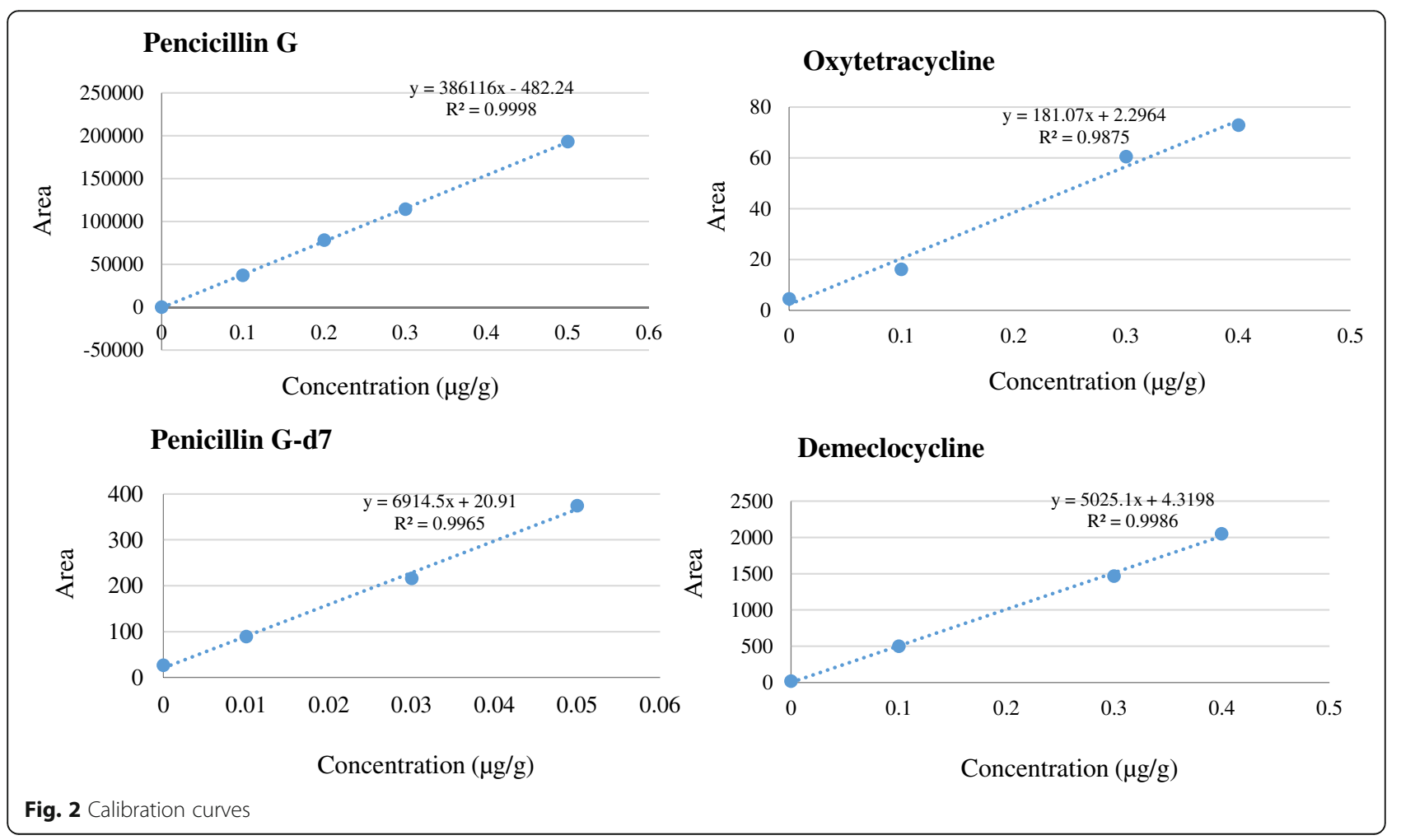



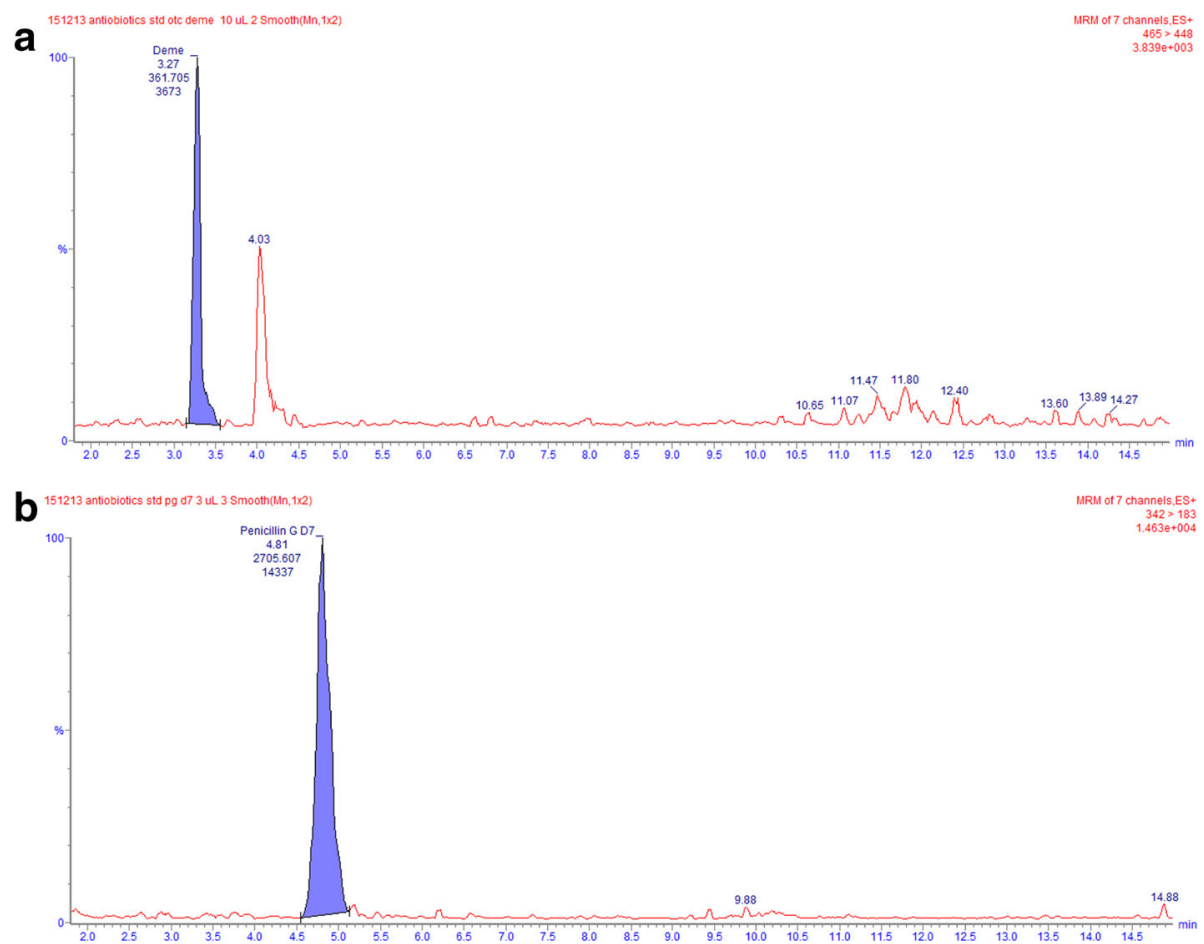

Fig. 3 Chromatograms of internal standards of demeclocycline (a) and Penicillin G-d7 (b)

Identification and dosage determination of drug residues in beef carcasses

For all the standards used, the correlation coefficient of standard curves varied from 0.9875 to 0.9998 (Fig. 2). Figures 3, 4, 5 and 6 present the chromatograms of the standards and some positive and reference samples used as controls.

\section{Percentage of cattle carcass positive sample}

Table 1 summarizes the percentage of contaminated cattle based on their demographics and factors related to their breeding. Overall, the carcasses of $20.30 \%$ (more than $1 / 5$ ) of the cattle studied were contaminated with antibiotic residues. Among them, $18.81 \%$ and $1.49 \%$ respectively contained the residues of penicillin $\mathrm{G}$ and oxytetracycline respectively. Among the carcasses contaminated with penicillin G residues, 28.95\% (11 of 38 cattle) contained concentrations above the maximum residues limit (MRL) $200 \mu \mathrm{g} / \mathrm{Kg}$.

We also found out that the number of transhumant cattle (31.25\%) whose carcasses were contaminated with antibiotic residues (penicillin $G$ and oxytetracycline) was significantly higher than those resulting from the sedentary system (19.35\%).

The percentage of beef produced from fattening and whose carcasses contained the residues of antibiotics studied was significantly low (17.39\%) compared to those from mixed $(26.67 \%)$ systems $(P<0.05)$. In addition, oxytetracycline residues were not found in the carcasses of any beef resulting from fattening.

From this table, it is evident that the percentage of sick cattle tested whose carcasses are contaminated with antibiotic residues is significantly higher (85.71\%) than that of the healthy cattle $(12.70 \%)(P<0.01)$.

Among the cattle breeds (Toupouri, Goudali and Red Fulani) whose carcasses were contaminated with antibiotic residues, the Red Fulani (2.08\%) and White Fulani (1.54\%) were the only ones whose carcasses contained oxytetracycline residues.

\section{Concentration of antibiotic residues in beef}

Considering the 404 liver and muscle samples analyzed, it appears that the mean concentration of penicillin $G$ residues in the beef of cattle slaughtered in Maroua was $17.58 \mu \mathrm{g} / \mathrm{kg}$. However, this concentration ranged from 0 to $1 \mathrm{mg} / \mathrm{kg}$ (20 times the MRL).

Table 2 shows the variation of the concentration of penicillin residues according to animal characteristics. Animals that had been identified by veterinarians after ante and/or post-mortem inspections with at least one pathology, their carcasses contained more penicillin residues than that of others. For this class of animals, the maximum penicillin residues obtained was $0.8 \mu \mathrm{g} / \mathrm{g}$. Also, as presented in the same table, the concentration average of penicillin $G$ residues recorded in the carcass samples from mixed farming 


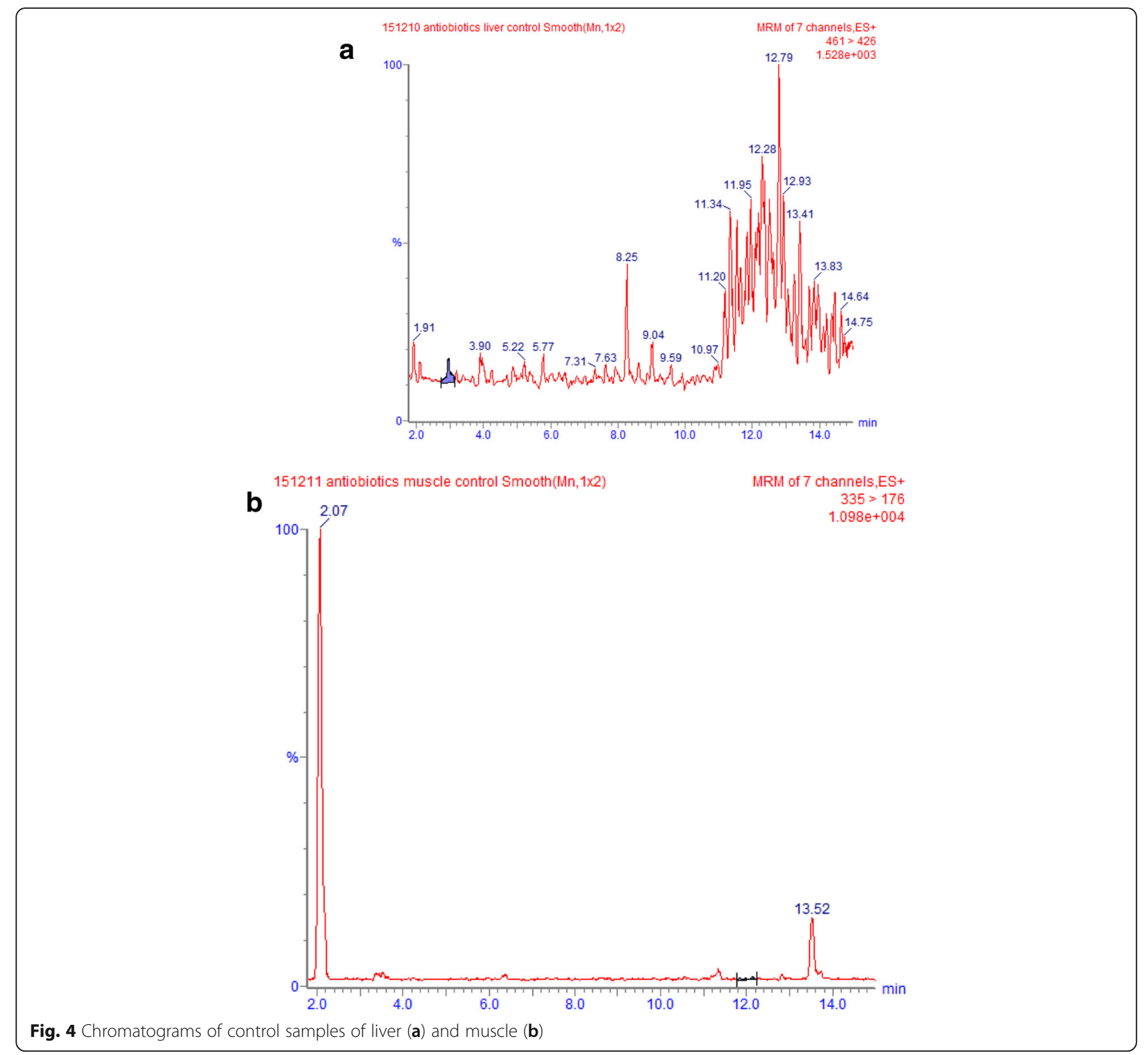

systems is higher $(0.263 \mu \mathrm{g} / \mathrm{g})$ than in the other categories of cattle with a variation ranging from $3 \times 10^{-3}$ to $0.77 \mu \mathrm{g} / \mathrm{g}$ (Table 2).

This table also shows that cattle carcasses from transhumant system were contaminated at significantly higher mean penicillin residue levels $(0.227 \mu \mathrm{g} / \mathrm{g})$ than animals from other livestock systems. The median concentration of penicillin residues obtained in carcasses of this cattle group was higher $(0.303 \mu \mathrm{g} / \mathrm{g})$ than in the other group and six times higher than the MRL. However, the highest concentrations were recorded in the animal carcasses from the sedentary system $(0.773 \mu \mathrm{g} / \mathrm{g})$. The results show also that the concentration of penicillin residues increases with the age of the animals.
Furthermore, the median concentration of the highest penicillin residues $(0.106 \mu \mathrm{g} / \mathrm{g})$ was recorded in the carcasses of the oldest animals. The median penicillin concentration in the liver is higher $(0.087 \mu \mathrm{g} / \mathrm{g})$ than in muscle $(0.055 \mu \mathrm{g} / \mathrm{g})$. In some liver samples, concentrations were six time higher than the MRL.

The mean concentration of oxytetracycline residues in beef consumed in Maroua is $0.24 \mu \mathrm{g} / \mathrm{g}$. These concentrations ranged from 0 to $22 \mu \mathrm{g} / \mathrm{g}$.

\section{Discussion}

The results obtained showed that the carcasses of $20.30 \%$ of the cattle sampled were contaminated with antibiotic residues, and among them $34.14 \%$ (14 out of 


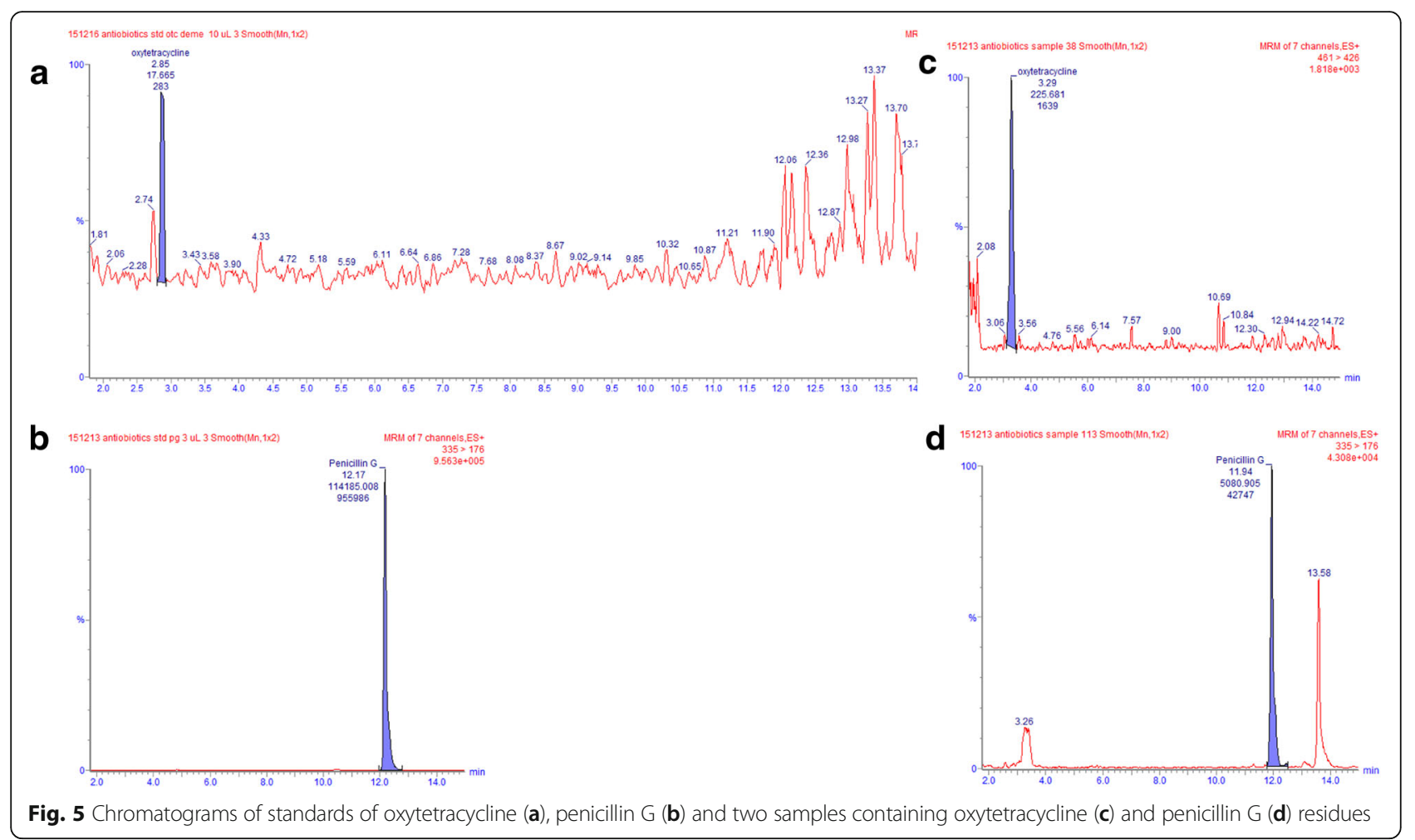

41) had residues above the MRLs $(200 \mu \mathrm{g} / \mathrm{Kg})$. This high proportion of contaminated carcasses could be explained by the fact that the majority of farmers in the Far North region do not respect the dosage of the veterinary medicines administered to their animals (Vougat et al. 2017). This poses a potential risk for consumers, as contaminated beef can lead to allergies, cancers, embryonic toxicities and even bacterial resistance in consumers (Aliu et al. 2001). This risk may have negative effects on the physical and chemical composition of the carcasses, leading to economic losses for butchers. This high percentage of contaminated beef could also have an impact on beef trade (Olatoye and Ehinmowo, 2009).

The proportion of contamination $(20.30 \%)$ is however smaller less than that obtained by Adesokan et al. (2013), Olatoye and Ogundipe (2009) and Olatoye and Ehinmowo (2009) in their analysis of the cattle samples collected in different slaughterhouses in several cities in Nigeria. Indeed, they obtained percentages of contamination of 100, 40 and $54.44 \%$ respectively. This difference

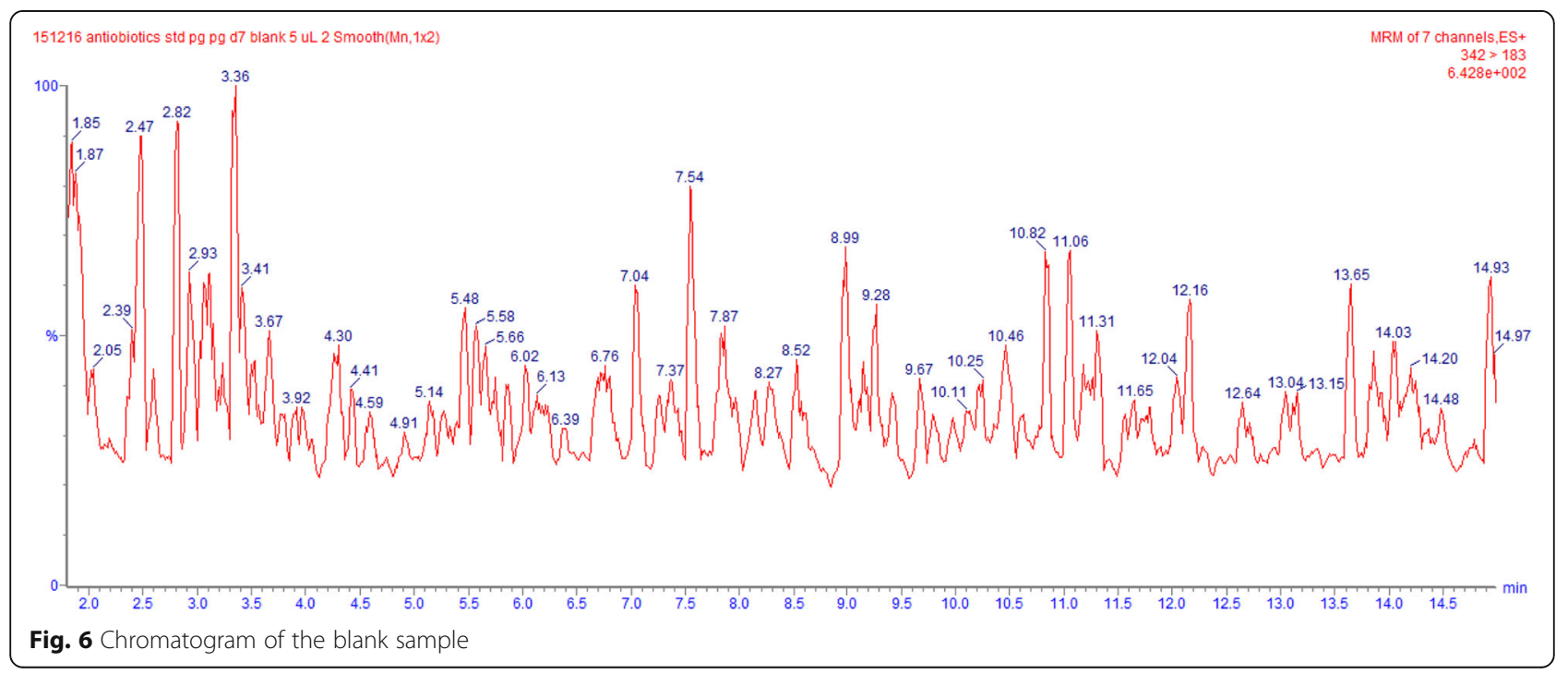


Table 1 Percentage (\%) of cattle carcasses contaminated according to their demographics

\begin{tabular}{|c|c|c|c|}
\hline Variables & $\begin{array}{l}\text { PEN } \\
\text { residues }\end{array}$ & $\begin{array}{l}\text { OTC } \\
\text { residues }\end{array}$ & $\begin{array}{l}\text { OTC }+ \\
\text { PEN residues }\end{array}$ \\
\hline \multicolumn{4}{|l|}{ Age (year) } \\
\hline$<8(n=37)$ & 18.92 & 0 & 18.92 \\
\hline $8-10(n=101)$ & 17.82 & 1.98 & 19.80 \\
\hline$>10(n=59)$ & 16.95 & 1.69 & 18.64 \\
\hline$N D(n=5)$ & 60 & 0 & 60 \\
\hline \multicolumn{4}{|l|}{ Sex } \\
\hline Entired male $(n=13)$ & 15.38 & 0 & 15.38 \\
\hline Castrated male $(n=4)$ & 0 & 0 & 0 \\
\hline Female $(n=185)$ & 19.46 & 1.49 & 21.08 \\
\hline \multicolumn{4}{|l|}{ Production system* } \\
\hline Transhumance $(n=16)$ & 25 & 6.25 & 31.25 \\
\hline Sedentary $(n=62)$ & 19.35 & 0 & 19.35 \\
\hline $\mathrm{ND}(n=124)$ & 17.74 & 1.61 & 19.35 \\
\hline \multicolumn{4}{|l|}{ Type of production* } \\
\hline Fattery $(n=46)$ & 17.39 & 0 & 17.39 \\
\hline Mixed $(n=30)$ & 23.33 & 3.33 & 26.67 \\
\hline $\mathrm{ND}(n=125)$ & 18.4 & 1.60 & 20 \\
\hline \multicolumn{4}{|l|}{ Health status** } \\
\hline Sick $(n=21)$ & 80.95 & 4.76 & 85.71 \\
\hline Healthy $(n=181)$ & 11.60 & 1.10 & 12.70 \\
\hline \multicolumn{4}{|l|}{ Body condition score } \\
\hline Thin $(n=131)$ & 18.32 & 1.53 & 19.85 \\
\hline Normal $(n=69)$ & 18.84 & 1.45 & 20.30 \\
\hline Fat $(n=1)$ & 100 & 0 & 100 \\
\hline \multicolumn{4}{|l|}{ Breed* $^{*}$} \\
\hline Goudali $(n=13)$ & 23.08 & 0 & 23.08 \\
\hline White Fulani $(n=65)$ & 18.46 & 1.54 & 20 \\
\hline Red Fulani $(n=96)$ & 20.83 & 2.08 & 22.92 \\
\hline Arabe Shuwa $(n=8)$ & 12.5 & 0 & 12.5 \\
\hline Toupouri $(n=3)$ & 33.33 & 0 & 33.33 \\
\hline Kapsiki $(n=9)$ & 11.11 & 0 & 11.11 \\
\hline Peul $(n=1)$ & 0 & 0 & 0 \\
\hline $\mathrm{ND}(n=7)$ & 0 & 0 & 0 \\
\hline \multicolumn{4}{|l|}{ Slaughterhouses } \\
\hline Municipal $(n=115)$ & 13.04 & 1.74 & 14.78 \\
\hline Makabaye $(n=45)$ & 22.22 & 0 & 22.22 \\
\hline Kongola $(n=26)$ & 26.92 & 0 & 26.92 \\
\hline Meskine $(n=8)$ & 25 & 12.5 & 37.50 \\
\hline Salak $(n=5)$ & 0 & 0 & 0 \\
\hline Godola $(n=3)$ & 100 & 0 & 100 \\
\hline
\end{tabular}

PEN penicillin G, OTC Oxytetracycline, ND No determined ${ }^{*} P<0.05,{ }^{* *} P<0.01$
Table 2 Concentration of penicillin residues on beef according to cattle demographics ( $n=202)$

\begin{tabular}{|c|c|c|c|c|}
\hline Variable & Mean & Median & Maximum & Minimum \\
\hline \multicolumn{5}{|l|}{ Sex } \\
\hline Male & 0.109 & 0.068 & 0.198 & 0.068 \\
\hline Female & 0.140 & 0.072 & 0.773 & 0.001 \\
\hline \multicolumn{5}{|l|}{ Age (year) } \\
\hline$<8$ & 0.108 & 0.094 & 0.198 & 0.009 \\
\hline$[8 ; 10]$ & 0.106 & 0.013 & 0.773 & 0.001 \\
\hline$>10$ & 0.192 & 0.106 & 0.734 & 0.003 \\
\hline \multicolumn{5}{|l|}{ Breed } \\
\hline Red Fulani & 0.143 & 0,072 & 0,773 & 0,001 \\
\hline White Fulani & 0.144 & 0.067 & 0.734 & 0.001 \\
\hline Goudali & 0.061 & 0.061 & 0.068 & 0.054 \\
\hline Kapsiki & 0.088 & / & / & / \\
\hline Arabe Shuwa & 0.119 & / & / & / \\
\hline Toupouri & 0.182 & / & / & / \\
\hline \multicolumn{5}{|l|}{ Tissus } \\
\hline Muscle & 0.054 & 0.055 & 0.090 & 0.009 \\
\hline Liver & 0.151 & 0.087 & 0.773 & 0.001 \\
\hline \multicolumn{5}{|c|}{ Body condition scoring } \\
\hline Fat & 0.128 & 0.128 & 0.196 & 0.061 \\
\hline Normal & 0.164 & 0.087 & 0.734 & 0.001 \\
\hline Thin & 0.124 & 0.066 & 0.773 & 0.001 \\
\hline \multicolumn{5}{|l|}{ Health status } \\
\hline Sick & 0.163 & 0.090 & 0.773 & 0.001 \\
\hline Healthy & 0.120 & 0.062 & 0.734 & 0.001 \\
\hline \multicolumn{5}{|c|}{ Type of production } \\
\hline Fattering & 0.096 & 0.061 & 0.337 & 0.001 \\
\hline Mixed $(n=6)$ & 0.263 & 0.211 & 0.773 & 0.003 \\
\hline ND & 0.121 & 0.070 & 0.734 & 0.001 \\
\hline \multicolumn{5}{|l|}{ Production system } \\
\hline Sedentary & 0.144 & 0.067 & 0.773 & 0.001 \\
\hline Transhumance & 0.227 & 0.303 & 0.325 & 0.054 \\
\hline ND & 0.123 & 0.072 & 0.734 & 0.001 \\
\hline
\end{tabular}

is due to the quality of the veterinary medicines sold in these two areas. Indeed, the poor quality (were not up to international quality standards) of medicinal products promotes the presence of residues of these drugs in animal products (Myllyniemi 2004; Gberindyer et al. 2014). In fact, the majority of medicines sold in Nigeria are of poor quality and the fact that Cameroon is one of the countries where these products are sold, could explain these results (Messomo 2006; Tomdieu, 2013). Percentages of the contamination higher than those recorded in this study were also noted by Ibrahim et al. (2009), Er et al. (2013) and Abdul Samad et al. (2014) in Nigeria 
(44\%), Turkey (57.7\%) and Pakistan (38.33\%) respectively. On the other hand, this percentage of contamination in our study area is higher than that of Dipeolu and Alonge (2002) and Morshdy et al. (2013) in the Dakahlia Province in Egypt (2\%) and Nigeria (16.11\%) respectively.

The proportion of cattle carcasses contaminated with penicillin residues $(18.81 \%)$ is significantly higher than those contaminated with oxytetracycline residues $(1.49 \%)$. This confirms the fact that penicillin is used more than oxytetracycline in the Far North region of Cameroon (Vougat et al. 2017). This trend was also observed in Nigeria (Ibrahim et al. 2009), where the percentage of contamination with penicillin residues was higher. This convergence confirms the fact that this molecule is one of the most widely used antibiotics in the veterinary sector worldwide (Emiri et al. 2014; Aalipour et al. 2015).

It also resulted from our analysis that the percentage of cattle from transhumant system whose carcasses contained antibiotic residues was significantly high (31.25\%) compared to animals from a sedentary system (19.25\%). This could be explained by the fact that in that region, all animals from transhumance system are treated by pastoralists. Unfortunately, all of the pastoralist do not respect the dosage indicated on the labels of veterinary drugs The fact that penicillin is used more than oxytetracycline clearly explains the difference observed between the two classes of drugs (Vougat et al. 2017).

Similarly, the proportion of animals with disease whose carcasses were contaminated with antibiotic residues $(85.71 \%)$ was significantly higher than that of healthy animals $(12.70 \%)$. This result can be explained by the fact during the period of this study, animals are generally highly infected and receive several veterinary treatments (Moritz et al. 2016).

The mean concentration of penicillin $G$ residues in the beef was $17.58 \mu \mathrm{g} / \mathrm{kg}$. This concentration is lower than the MRL $(50 \mu \mathrm{g} / \mathrm{kg})$. This could be attributed to the probably low doses of antimicrobials commonly administered by pastoralists in order to maximize the number of doses available (Olatoye and Ehinmowo, 2009). This concentration is higher than that obtained in beef consumed in the southwestern Nigeria $(8.81 \mu \mathrm{g} / \mathrm{kg})$ (Adesokan et al. 2013).

Unlike several studies carried out worldwide, this study highlights the influence of several factors on the rate of contamination by the residues of penicillin $G$ and oxytetracycline in beef consumed in Maroua city. It was found that the average concentration of penicillin $G$ residues in bovine carcasses was higher in sick cattle compared with those tested negative during ante and post mortem diagnostics. This clearly demonstrates that sick animals may have received treatment a few days before slaughtering, which would justify failure to comply with the withdrawal period indicated on the veterinary drug labels.

The mean concentration of penicillin residues in carcasses of older cattle (over 10 years) was significantly higher than that of younger animals. Indeed, in our study area and during the period when our data were recorded (period of death), the oldest animals are the most susceptible to diseases and thus receive several treatments based on veterinary drugs.

The average concentration of oxytetracycline residues in the beef consumed in Maroua was $240 \mu \mathrm{g} / \mathrm{kg}$. This concentration was lower than the MRL $(600 \mu \mathrm{g} / \mathrm{kg})$. Though lower than MRL, presence of residues highlights once again the misuse of drugs in the Far North region of Cameroon (Vougat et al. 2017) and the need to solve this public health problem. The concentration of 240 $\mu \mathrm{g} / \mathrm{kg}$ is, however, significantly higher than that obtained in the South-West of Nigeria $(12.79 \mu \mathrm{g} / \mathrm{kg})$ by Adesokan et al. (2013). This shows the high level of contamination in this study zone and also in Nigeria where, all the samples analyzed contained the residues of this antibiotic. Lower concentrations than that those found in this study were noted by Bedada et al. (2012) in Ethiopia.

\section{Conclusion}

The results obtained in this study showed that $20.3 \%$ of the carcasses of the cattle slaughtered in Maroua and Godola were contaminated with antibiotic residues. This percentage of positive samples was relatively high compared to those found in studies in others African countries. The meat of cattle from transhumance system, sick animals, and older cattle was more likely to contained penicillin $\mathrm{G}$ and oxytetracycline residues. Analysis indicated that beef sold in Maroua was found to be with high levels of antibiotic residues as compared to other studies. Beef contamination by antibiotics may pose a health threat to consumers in the Far North Region of Cameroon. Strict regulation on the use of antimicrobial drugs in the livestock sector and associated testing of animal-derived food sources prior to marketing are required. This work can serve as an initial step to assess the dietary exposure to antibiotic residues through beef consumption in Cameroon.

\section{Additional file}

Additional file 1: Materials and Method for the determination of Penicillin $\mathrm{G}$ and oxytetracycline residues. (DOCX $21 \mathrm{~kb}$ )

Abbreviation

MRL: Maximum residues limit 


\section{Acknowledgements}

The authors are thankful to those butchers who kindly authorized us to collect tissues on their cattle. We are grateful to Ms. NDZANA M. Vincent de Paul and Danwang for helping in sample collection. The authors also wish to thank Dr Mark Moritz and Dr. Roland Ziebe for their helpful discussion. A great acknowledgement goes to the Far North Regional Delegation of the Ministry of Livestock, Fisheries and Animal Industries (MINEPIA) for granting research permission and the Institute of Medical Researches and Medicinal Plants Studies (IMPM). We would like to thank all the reviewers whose constructive comments improved the overall quality of this manuscript.

\section{Funding}

This research was funded by the U.S. National Science Foundation (DEB1015908) via a fellowship from the Disease Ecology and Computer Modeling Laboratory (DECML) of the Ohio State University (US).

\section{Availability of data and materials}

The datasets used/or analyzed during the current study are available from the corresponding author on reasonable request.

\section{Authors' contributions}

This paper is the product of an interdisciplinary collaboration between the University of Maroua (Cameroon), the Disease Ecology and Computer Modeling Laboratory of the Ohio State University (USA) and the Veterinary Diagnostic and Production Animal Medicine of The lowa State University (USA). The study was conceived and designed by RRBVN and RBG. The field work was supervised by RBG (veterinary epidemiologist), HSF (animal physiologist and pharmacologist) and ZPA (tropical animal health specialist, veterinarian). RRBVN collected the data. The sample testing was overseen by the lowa State team: DES (technician), WKR (veterinary toxicologist), and DS (toxicologist) who supervised RRBVN during the laboratory analysis. Data was analyzed by DS and RRBVN. RRBVN wrote the manuscript. All authors read and approved the final manuscript.

\section{Authors' information}

RRBVN is currently a Ph.D. Student in the Department of Biological Sciences in the University of Maroua in Cameroon focusing on toxicology and pharmacology of medications used to treat cattle in Cameroon and their human health implication. WKR is board-certified in toxicology, his research area is in translational toxicology of environmental toxicants on human and animal health. He has a keen interest in toxicological issues in developing countries. He is currently investigating the efficacy of cobinamide for treatment of hydrogensulphide-induced neurotoxicity, the development and validation of a tissue-based diagnostic test for aflatoxin B1 in liver and urine, and the cyanotoxin-applied research, diagnostic test methods, and impact of microcystin LR on human health and animal health. RBG is a veterinarian and epidemiologist whose research focuses on applications of mathematical modelling and statistics in the field of transboundary animal diseases. DS research interest have spanned from method development of trace ion analysis, characterization of metal thin film, to analysis of biological macromolecules. His is current research efforts focus on development and inter-lab validation of an analytical method for determination of aflatoxin M1 and $\mathrm{B} 1$ in liver.

\section{Ethics approval}

Not applicable.

\section{Consent for publication}

Not applicable.

\section{Competing interests}

The authors declare that they have no competing interests.

\section{Publisher' Note}

Springer Nature remains neutral with regard to jurisdictional claims in published maps and institutional affiliations.

\section{Author details}

'Department of Biological Sciences, Faculty of Sciences, University of Maroua, P.O Box: 814, Maroua, Cameroon. ${ }^{2}$ Department of Veterinary Preventive Medicine, College of Veterinary Medicine, The Ohio State University, 1920
Coffey Rd., Columbus, OH 43210, USA. ${ }^{3}$ Veterinary Diagnostic and Production Animal Medicine, College of Veterinary Medicine, lowa State University, Ames, IA 50011, USA. ${ }^{4}$ School of Veterinary Medicine and Sciences, University of Ngaoundéré, Ngaoundéré, Cameroon.

Received: 28 April 2017 Accepted: 6 November 2017

Published online: 21 November 2017

\section{References}

Aalipour F, Mirlohi M, Jalali M, Azadbakht L. Dietary exposure to tetracycline residues through milk consumption in Iran. J Environ Health Sci Eng. 2015;13: 80. doi:10.1186/s40201-015-0235-6..

Abdul Samad M, Khaskheli M, Aijaz HS, Ghiasddin MS. Antibiotic residues detection in raw beef meat sold for human consumption in sindh, Pakistan. Int J Res Appl Nat Soc Sci. 2014;2(7):15-20.

Adesokan HK, Agada CA, Adetunji VO, Akanbi IM. Oxytétracycline and penicillin-G residues in cattle slaughtered in southwestern Nigeria: implications for livestock disease management and public health. J S Afr Vet Assoc. 2013: 84(1):5.

Aliu Y, Mammah M, Abdullahi US. Optimal Livestock Production in Nigeria; value of medicinal products and food safety consideration. A lecture delivered at the IITA Ibadan. 2001.

Bedada AH, Zewde BM, Zewde BM. Tetracycline residues levels in slaughtered beef cattle from three slaughterhouses in Central Ethiopia. Global Veterinaria. 2012;8(6):546-54

Beyene T. Veterinary drug residues in food-animal products: its risk factors and potential effects on public health. J Veterinar Sci Technol. 2016;7(1):1-7. http://dx.doi.org/10.4172/2157-7579.1000285.

Borràs $S$, Companyó R, Granados $M$, Guiteras J. Analysis of antimicrobial agents in animal feed. TrAC Trends Anal Chem. 2011;30(7):1042-64.

Bousova K, Senyuva H, Mittendorf K. Quantitative multi-residue method for determination antibiotics in chicken meat using turbulent flow chromatography coupled to liquid chromatography-tandem mass spectrometry. J Chromatogr A. 2013;1274:19-27.

CAC/MRL. Limites Maximales de Résidus (LMR) et Recommandations de Gestion des résidus (RGR) des médicaments vétérinaires dans les aliments. Mises à jour à la trente-huitième session de la Commission du Codex Alimentarius (juillet 2015). 2015. p. 45.

Chicoine AL. An investigation of intraperitoneal procaine penicillin $\mathrm{g}$ administration in lactating dairy cows. Dissertation, University of Saskatchewan, Canada; 2007.

Chillaud T. L'Accord sur l'application des mesures sanitaires et phytosanitaires de I'Organisation mondiale du commerce Rev. sci. tech. Off. int. Epiz.11996;15(2): 743-751. https://www.oie.int/doc/ged/D9068.PDF. Accessed 17 Nov 2017

Crévat J. Rational feed of animals. Estimated of the weight by measurement. J Agr Pract. 1980.

Dipeolu MA, Alonge DA. Residues of streptomycin antibiotic in meat sold for human consumption in some states of SW Nigeria. Arch Zootec. 2002;51: 477-80.

Djamen NP. Territoire, filière et temps : modalités et enjeux de l'insertion marchande des systèmes d'élevage bovins au Nord Cameroun. Thèse présentée en vue de l'obtention du grade de Docteur (Ph.D). Dschang: AgroParisTech, Paris (France)/Université de Dschang (Cameroun); 2008. p. 230.

Dongmo AL, Djamen NP, Vall E, Koussou MO, Coulibaly D, Lossouarn J. L'espace est fini! Vive la sédentarisation? Innovations et développement durable en question chez les pasteurs des zones cotonnières d'Afrique de l'Ouest et du Centre. Rencontre autour des Recherches sur les Ruminants. 2007;13:153-60.

Donkor ES, Newman MJ, Tay SCK, Dayie NTKD, Bannerman E, Olu-Taiwo M. Investigation into the risk of exposure to antibiotic residues contaminating meat and egg in Ghana. Food Control. 2011;22:869-73.

Edima HC, Tofaing JT, Ngoune LT, Ndjouenkeu R. Assessment of antibiotic residues in cow milk produced in Ngaoundere. Int J Biol Pharmacol Appl Sci. 2012;1(11):1530-8.

Emiri A, Myftari E, Çoçoli S, Treska E. Determination of oxytetracycline, tetracycline and chlortetracycline in beef meat by HPLC-DAD detector in Albania. Albanian J Agric Sci (Special edition). 2014;489-93.

Er B, Onurdag FK, Burak D, Özgacar SÖ, Öktem AB, Abbasoğlu U. Screening of quinolone antibiotic residues in chicken meat and beef sold in the markets of Ankara, Turkey. Poult Sci. 2013;92(8):2212-5. doi:10.3382/ps. 2013-03072. 
FAO. Manuel pour les agents vétérinaires communautaires. 1995. http://www.fao. org/docrep/t0690f/t0690f00.htm. Accessed 15 Nov 2017.

FSIS. National residue program of United States Department of Agriculture [Internet]. 2011. Available from: http://www.fsis.usda.gov. Accessed 15 Nov 2017.

Gberindyer FA, Onyeyili PA, Bosha JA. Quality control properties of some brands of veterinary albendazole boluses common in Nigeria. J Pharm Pharmacol. 2014;2:135-9.

Guetiya WER, Zambou RF, Anyangwe FF, Njimou JR, Coman RR, Verdenelli MC, Cecchini C, Silvi S, Orpianesi C, Cresci A, Colizzi V. Abusive use of antibiotics in poultry farming in Cameroon and the public health implications. Br Poult Sci. 2016;57(3);493-783.

Hou XL, Chen G, Zhu L, Yang T, Zhao J, Wang L, Wu YL. Development and validation of an ultrahigh performance liquid chromatography tandem mass spectrometry method for simultaneous determination of sulfonamides, quinolones and benzimidazoles in bovin. J Chromatogr B Analyt Technol Biomed Life Sci. 2014;962:20-9.

Ibrahim A, Junaidu A, Garba M. Multiple antibiotic residues in meat from slaugthered cattle in Nigeria. The internet. J Vet Med. 2009;8(1):1-5.

Kaneene JB, Miller R. Problems associated with drug residues in beef from feeds and therapy. Revue scientifique et technique (International Office of Epizootics). 1997;16(2):694-708.

Kang J, Hae-Chul P, Vinayakumar G, Su-Jeong P, Myeong-Ae K, Min-Kyoung K, Hyun-Jung K, Byung-Hoon C, Tae-Wan K, Kwang-Jick L, Chae-Mi L. Veterinary drug residues in domestic and imported foods of animal origin in the Republic of Korea. Food Addit Contam Part B Surveill. 2015;8(2):106-12. doi: 10.1080/19393210.2014.1001795.

Keegan J, O'Kennedy R, Crooks S, Elliott C, Brandon D, Danaher M. Detection of benzimidazole carbamates and amino metabolites in liver by surface plasmon resonance-biosensor. Anal Chim Acta. 2011;700(1):41-8.

Messomo FN. Etude de la distribution et de la qualité des médicaments vétérinaires au Cameroun. Thèse de Doctorat. Ecole Inter-états des sciences et médecine vétérinaires; 2006. http://www.beep.ird.fr/collect/eismv/index/ assoc/TD06-7.dir/TD06-7.pdf. Accessed 15 Nov 2017.

MINEPIA. 2014 Statistical yearbook of the Ministry of Livestock, Fisheries and Animal Industries of Cameroon. 2015. p. 113.

Moritz M, Laborde S, Phang SC, Ahmadou M, Durand M, Fernandez A, Hamilton IM, Kari S, Mark B, Scholte P, Xiao N, Ziebe R. Studying the Logone floodplain, Cameroon, as a coupled human and natural system. Afr J Aquat Sci. 2016; 41(1):99-108. doi:10.2989/16085914.2016.1143799.

Morshdy AE, El-Atabany Al, Hussein MA, Darwish WS. Oxytetracycline residues in bovine carcasses slaughtered at Mansoura abattoir, Egypt. Jpn J Vet Res. 2013;61(Suppl):S44-7.

Myllyniemi AL (2004) Development of microbiological methods for the detection and identification of antimicrobial residues in meat. Doctoral dissertation, University of Helsinki. National Veterinary and Food Research Institute (EELA) Helsinki, Finland.

Nicholson MJ, Butterworth MH. Grille de notation de l'état d'engraissement des bovins zébus. Addis-Abeba: Centre International Pour l'Elevage en Afrique (CIPEA); 1989. p. 37

Nisha AR. Antibiotics residues-a global health hazard. Vet World. 2008;1(12):375-7.

Olatoye IO, and Ehinmowo AA. Oxytetracycline residues in edible tissues of cattle slaughtered in Akure, Nigeria. Internet Journal of Food Safety, 2009;11:62-66.

Olatoye Ol, Ogundipe GAT. Preliminary screening of beef consumed in Ibadan Nigeria for antibacterial residues. Afr J Biomed Res. 2009:12(3):245-7.

Pater S (2007) How much does your animal weigh? Winter 11-12.

Petrović JM, Katić VR, Bugarski DD. Comparative examination of the analysis of $\beta$ lactam antibiotic residues in milk by enzyme, receptor-enzyme, and inhibition procedures. Food Anal Methods. 2008;1:119-25. doi:10.1007/ s12161-007-9007-y.

Pouokam GB, Foudjo BUS, Samuel C, Yamgai FP, Silapeux AK, Sando JT, Atonde GF, and Frazzoli C. Contaminants in Foods of Animal Origin in Cameroon: A One Health Vision for Risk Management "from Farm to Fork"Front Public Health. 2017;5: 197. doi:10.3389/fpubh.2017.00197. Accessed 16 Nov 2017.

Thrusfield M. Veterinary epidemiology. 3nd eds. Oxford: Blackwell; 2007.

USDA. APHIS Foot-and-Mouth Disease (FMD) Response Plan: The Red Book National Preparedness and Incident Coordination CenterVeterinary Services Animal and Plant Health Inspection Service U.S. Department of Agriculture; 2014. p. 234.
USDA (United States Department of Agriculture)/Food Safety and Inspection Service, Office of Public Health Science. Screening and confirmation of animal drug residues by UHPLC-MS-MS. Theol Rev. 2014;04:36.

VMD (Veterinary Medicines Directorate). Annual report on surveillance for veterinary residues in food in the UK [Internet]. [cited 2012 Jul 3]. 2011. Available from: https://www.gov.uk/government/uploads/system/uploads/ attachment_data/file/243614/9780108507656.pdf. Accessed 15 Nov 2017.

Vougat NRRB, Chouto S, Foyet HS, Garabed R, Ziebe R, Zoli PA. Beef consumption and consumer's knowledge on meat quality in Maroua in the far north of Cameroon. Afr J Food Sci. 2016;10(8):122-31.

Vougat NRRB, Tomdieu T, Ziébé R, Foyet HS, Moritz M, Vondou L, Schrunk DE, Imerman PM, Rumbeiha WK, Garabed RB. Quality of veterinary pharmaceuticals and their use by pastoralists in the far north region of Cameroon. Pastoralism: research, policy and. Practice. 2017;7:6.

Wang J, Leung D, Lenz SP. Determination of five macrolide antibiotic residues in raw milk using liquid chromatography-electrospray ionization tandem mass spectrometry. J Agric Food Chem. 2006;54:2873-80.

\section{Submit your manuscript to a SpringerOpen ${ }^{\circ}$ journal and benefit from:}

- Convenient online submission

- Rigorous peer review

- Open access: articles freely available online

- High visibility within the field

- Retaining the copyright to your article

Submit your next manuscript at $>$ springeropen.com 